\title{
Varroa destructor reproduction and cell re-capping in mite-resistant Apis mellifera populations
}

\author{
Stephen J. Martin ${ }^{1}$, George P. Hawkins ${ }^{1}$, Laura E. Brettell ${ }^{2}$, Natasha Reece ${ }^{1}$, \\ Maria E. Correia-OliveirA ${ }^{3}$, Michael H. Allsopp ${ }^{4}$ \\ ${ }^{1}$ School of Environment and Life Sciences, The University of Salford, M5 4WT, Manchester, UK \\ ${ }^{2}$ Hawkesbury Institute for the Environment, Western Sydney University, Locked bag 1797, Penrith, Richmond, NSW \\ 2751, Australia \\ ${ }^{3}$ Universidade Federal do Recôncavo da Bahia, Rua Rui Barbosa 710, Cruz das Almas, Bahia 44380-000, Brazil \\ ${ }^{4}$ ARC-Plant Protection Research Institute, P/Bag X5017, Stellenbosch 7599, South Africa
}

Received 6 June 2019 - Revised 17 September 2019 - Accepted 7 November 2019

\begin{abstract}
Globalization has facilitated the spread of emerging pests such as the Varroa destructor mite, resulting in the near global distribution of the pest. In South African and Brazilian honey bees, mite-resistant colonies appeared within a decade; in Europe, mite-resistant colonies are rare, but several of these exhibited high levels of "recapping" behavior. We studied re-capping in Varroa-naïve (UK/Australia) and Varroa-resistant (South Africa and Brazil) populations and found very low and very high levels, respectively, with the resistant populations targeting mite-infested cells. Furthermore, 54\% of artificially infested A. m. capensis worker cells were removed after 10 days and $83 \%$ of the remaining infested cells were re-capped. Such targeted re-capping of drone cells did not occur. We propose that cell opening is a fundamental trait in mite-resistant populations and that re-capping is an accurate proxy for this behavior.
\end{abstract}

re-capping / hygienic / tolerance / resistance / Varroa

\section{INTRODUCTION}

During the past 70 years, the ectoparasitic "Varroa" mite (Varroa destructor) has spread worldwide and has become the greatest threat for apiculture, killing large numbers of managed Apis mellifera honey bee colonies (Rosenkranz et al. 48), while decimating feral and wild populations (Wenner et al. 56). Many beekeepers originally advocated breeding from

Electronic supplementary material The online version of this article (https://doi.org/10.1007/s13592-019-00721-9) contains supplementary material, which is available to authorized users.

Corresponding author: S. Martin, s.j.martin@salford.ac.uk

Manuscript editor: Peter Rosenkranz stock that survived, but in the vast majority of cases, their colonies ultimately died, since any preexisting defense adaptations were either not sufficiently developed or were overwhelmed by the massive number of mites initially circulating in the population. As such, countries across the Northern Hemisphere, and those (e.g., Argentina, New Zealand) which had imported Northern Hemisphere honey bees that subsequently became infested by Varroa, were forced to use miticides to control mite numbers and to protect their bee populations.

By contrast, and although the evolution of defense mechanisms can occur rapidly $(<100$ years) but is rarely seen occurring simultaneously in allopatric populations (Thompson 52), in South Africa and Brazil, their honey bees quickly became resistant to Varroa 
(Rosenkranz 46). That is, they did not receive nor require the administering of any mitecontrol methods to ensure their long-term survival, and no population-wide loss of colonies occurred.

The Western honey bee A. mellifera, which consists of approximately 30 geographical subspecies, originated in Africa and appears to have expanded twice into Eurasia, followed by a more recent anthropogenic expansion into the Americas (including Brazil, see below), Asia, and Australasia (Whitfield et al. 57). African honey bees are resilient to many of the pathogens and parasites that often plague (and need to be controlled) in other parts of the world, as evidenced by the limited pest management practiced in Africa (Pirk et al. 42). The Varroa mite arrived in Africa in 1997 to the Cape Region of South Africa (Allsopp 1). This was initially followed by some colony losses; however, these were short-lived, with mite resistance appearing after 3-5 years in the Cape honey bee (A. m. capensis) and 6-7 years in the Savanna honey bee (A. $m$. scutellata) (Allsopp 1). This pattern of shortlived colony loss prior to the appearance of mite resistance is frequently mentioned in other mite-resistant populations (e.g., Fries et al. 12; Mordecai et al. 33; Oddie et al. 37).

The Africanized honey bee (AHB) is a hybrid between A. m. scutellata from South Africa and East Africa, and various European races, e.g., A. m. iberiensis and A. m. ligustica. In 1957, 26 swarms of A. m. scutellata spread northwards throughout Brazil from Rio Claro, hybridizing with European races to form the AHB which reached the USA in 1990 (Winston 58). In 1971, during this expansion, the Varroa mite arrived in Brazil (Moretto et al. 34) and spread rapidly throughout both the AHB and European honey bees. The subsequent establishment of AHB throughout the tropical and subtropical regions of South America was due, in part, to AHBs' natural resistance to Varroa (Rosenkranz 46). In both AHB (Camazine 8; Medina et al. 27; Mondragon et al. 32) and A. m. scutellata (Martin and Kryger 23; Nganso et al. 36), poor mite reproduction limits their population growth, although the mechanism(s) by which this occurs has remained unknown.

Targeted selective bee-breeding programs to combat Varroa have been ongoing for decades in both America (Rinderer et al. 45) and Europe (Büchler et al. 7). Selection for traits such as hygienic behavior (based on the removal of killed sealed brood) is being used by beekeepers to help reduce their mite treatment regime, and the Varroa Sensitive Hygiene (VSH) line (developed from Suppression of Mite Reproduction lines) that targets the removal of living mite infested brood (e.g., Harris 16) is undergoing further selection in Hawaii to make it suitable for use in beekeeper operations. Meanwhile, naturally selected miteresistant populations are being maintained without any mite control measures across a vast range of environments, i.e., that exists across Africa and South and Central America.

Recently, low rates of mite reproduction similar to those found in African and AHB were reported in four European mite-resistant populations (Oddie et al. 37), which raised the possibility that a similar mechanism had arisen in these geographically distinct populations. Oddie et al. (38) then linked the low mite reproduction in these European populations with a high incidence of "re-capping" behavior, when a cell containing a developing pupa has its silk/wax cap partially removed by the worker bees and then resealed with wax, without the removal of the pupa. Although re-capping (even of mite-infested cells) is not a new phenomenon, e.g., both hygienic and non-hygienic colonies re-capped around $90 \%$ of artificially created holes in the cell caps (Spivak and Gilliam 51), its importance may have previously been overlooked.

The aim of this study was to investigate mitenaïve populations from Scotland, Isle of Man and Australia, and well-established mite-resistant populations from Brazil (AHB) and South Africa (A. m. scutellata and A. m. capensis ), to identify whether re-capping is a reliable proxy for miteresistance, and whether it is associated with reduced mite reproduction. We then focused on A. m. capensis, which was found to have the highest targeted re-capping of mite-infested cells.

\section{METHODS}




\subsection{Varroa-mite naïve colonies}

During 2018, Varroa-naïve brood samples were obtained from three colonies, each from a different apiary, from across the Island of Colonsay, Scotland, UK, and three colonies from a single apiary belonging to Western Sydney University, Hawkesbury Campus, NSW, Australia. Four additional Varroa-naïve colonies were sampled in 2019 from the Isle of Man, UK.

\subsection{Mite-resistant AHB colonies, Brazil}

The AHB were located at Cruz das Almas, Bahia State, NE Brazil. Re-capping and mite reproduction were studied in February 2018, using six colonies (minimum of 300 worker cells per colony). Re-capping rates and mite infestation data were collected from an additional ten colonies (150-200 worker cells per colony) which were used in a freeze-kill brood removal test.

\subsection{Mite-resistant South African colonies}

Four A. m. scutellata colonies were studied in July 2018 and again in March 2019, while 20 A. $m$. capensis colonies were studied in July 2018 $(n=3)$ and in March $2019(n=17)$ (Tables I and S1). As only one A. m. scutellata and two A. $m$. capensis colonies contained drone brood, in addition, ten A. m. capensis colonies with drone brood were sampled. All colonies are maintained within $20 \mathrm{~km}$ of Stellenbosch, Western Cape, South Africa, with the four A. m. scutellata colonies having been moved $800 \mathrm{~km}$ from their natural distribution into the area for research purposes. As no mite-susceptible colonies are present in either Brazil or South Africa, no direct comparisons with treated colonies from the same region are possible, although as African bees are the ancestral population both resistant and susceptible populations all originated from Africa (Whitfield et al. 57).

\subsection{Cell re-capping}

From each colony, a single frame containing mainly purple eyed pupae (e.g., 180-190 hpc) or older worker or drone brood was removed, and on average, 300 cells per colony (Table S1) were examined for re-capping and mite reproduction. To determine whether a cell was re-capped, fine forceps were used to carefully cut around the edge of the cap, which was then inverted to allow the underside to be inspected under a binocular microscope $(\times 16)$. If the silk cocoon spun during the first $30 \mathrm{~h}$ of the sealed stage (Martin 19) had been partially removed and replaced by wax, it was classified as re-capped. The diameter of the re-capped area for worker brood was estimated to the nearest $\mathrm{mm}$.

\subsection{Mite reproduction in worker brood}

After the re-capping status of the cell had been determined, the pupa was carefully removed and aged according to standard methods (Dietemann et al. 11). If the cell was infested, then all mites, offspring, and shed skins (exuviate) were removed and the mite family reconstructed using the method and developmental chart of Martin (19). Only the 497 infested cells containing yellow-thorax pupae or older, i.e., over $190 \mathrm{~h}$ since the cell had been capped, were used in the reproductive calculations (Table S2). The number of mated adult female offspring were counted, that is the cell must also contain a living adult male (evidenced by the exuviate), accompanied by daughters at the correct developmental stage. Only the number of foundresses per cell was determined in the drone brood. Two methods were used to calculate the average number of mated female offspring produced during one reproductive cycle in each of the three study populations, since not all samples are at the same developmental stage; therefore, any mite mortality from the sampling point to bee emergence will not be accounted for. Therefore, firstly, we counted the total number of mated female offspring and divided it by the number of invading foundresses. Secondly, we counted the number of females that would be mated and were assumed to mature prior to bee emergence, but accounted for a further in-cell mortality in cells younger than grey pads, by multiplying the first daughter by 0.94 , the second daughter by 0.38 , and third daughter by 0.13 . These mortality values were based on a study of over 1000 mite families (Martin 19). The 
results of both calculations are provided (Table S2) and are similar.

\subsection{Artificial infestation of $A$. m. capensis cells with Varroa}

Since the pattern of Varroa infestation within and among frames is non-random (Fuchs 13), we studied the bees' ability to detect and remove mite-infested pupae by artificially infesting cells with mites (Boecking 5; Rosenkranz et al. 47) rather than comparing relative changes in infestation levels over a period of time (Harris 15). Therefore, a total of 390 mother mites harvested from A. m. capensis drone brood cells containing a stretched larva were inserted into $A . m$. capensis worker cells that were less than 1 day post-capping, as indicated by the lack of a completed cocoon (Martin 19). Of these mites, 325 were alive and 65 had died since been collected the previous day. Dead mites were also used for artificial infestation experiments, as comparing rates of detection using living vs dead mites may help indicate cues used to detect infested cells, e.g., movement. A frame containing cells capped within the past $24 \mathrm{~h}$ were as evidence by the larvae spinning their cocoons, were removed from each of $11 \mathrm{~A}$. m. capensis colonies over a period of several days. Freshly sealed cells were opened, and a mother mite inserted using a fine paint brush before re-sealing the cell and recording its position on an acetate sheet. After returning the frames to their colonies, an inspection after $24 \mathrm{~h}$ revealed any cells removed by the bees as a result of the manipulation. Five days later (6 days post-capping), the number of pupae removed from the artificially infested cells were recorded. After 10 days (11 days post-capping), each frame was removed and any remaining artificially infested cells were inspected for mites, and the state of the cell cap (i.e., re-capped or not) was recorded (Table S3). We also inspected the cap condition of a similar number of neighboring non-infested control cells. Insufficient mites were available to conduct artificial infestation experiments in AHB. 


\section{freeze-killed brood.}

In ten AHB and 11 A. m. capensis colonies, their ability to remove freeze-killed pupae (classic hygienic behavior) was studied to compare with their re-capping rates. An area of purple-eyed pupae or older ( $>7$ days post-capping) was freeze-killed using liquid nitrogen, and then the number of removed pupae determined after $24 \mathrm{~h}$ and $48 \mathrm{~h}$ (Table S3). The $48 \mathrm{~h}$ data was not analyzed since several of the colonies in both populations had removed $100 \%$ of the killed brood by $48 \mathrm{~h}$.

\subsection{Data analysis}

All datasets were non-normally distributed, thus statistical tests included chi-squared, Kolmogorov-Simirnov, Mann-Whitley $U$, Wilcoxon signed-rank, and Spearman's rank correlation. The test statistic indicates which test was used if not mentioned in the text.

\section{RESULTS}

\subsection{Cell re-capping and mite reproductive behavior in worker cells}

Based on 497 infested cells, we confirmed that the average number of mated female offspring produced per mother foundress during a single reproductive cycle $(\mathrm{Wr})$ was between 0.8 and 0.9 in the three mite-resistant populations (Table I, Table S2), with only $54-55 \%$ of the invading mothers reproducing, and producing between 1 and 3 mated female offspring each. Across the ten Varroa-naïve colonies from three different populations, only $0.5 \%$ (median) of the worker sealed brood cells were re-capped (Table I, Table S1, Figure S1). In contrast, the median recapping rates in the Varroa-resistant AHB, A. m. scutellata and A. m. capensis were $35 \%, 20 \%$ and $27 \%$, respectively, although the average infestation rate was $<10 \%$ in every mite-resistant population. The re-capping rate of infested cells was always significantly higher than for non-infested cells (AHB $U=17, z=2.46, p=0.014 ; A$. $m$. scutellata $U=0, z=3.31, p<0.001$; and $A$. $m$. capensis $U=10.5, z=4.41, p<0.0001$ )
(Table S1, Figure S1). Combining the data from the three populations, we found that the estimated number of viable offspring in re-capped (0.82) and undisturbed $(0.76)$ cells were similar (Table S2). The frequency distribution of the size of the re-capped area (diameter of the opening which had been resealed) of non-infested cells in all four populations followed the same negative trend (Figure 1a-d). In contrast, infested cells all had significantly different size distributions (AHB, $D=0.2051, p=0.002 ; A$. m. scutellata $D=0.3406, p<0.0001$ and $A$. m. capensis, $D=$ $1, p=0.037)$ due to the re-capped area being larger, i.e., larger than $3 \mathrm{~mm}$, if the cell was infested in all three populations (Figure 1e, f). Furthermore, all re-capped cells in the Varroanaïve populations were small ranging from 1 to $3 \mathrm{~mm}$. Re-capped cells appeared from the early stages of pupal development and their proportion increased steadily as the pupae developed (Figure 1h). We noticed that some infested cells had been re-capped more than once, as they contained two or three distinct holes cut out of the silk cap.

\subsection{Cell re-capping and mite infestation in A.m. capensis drone cells}

The average infestation level of drone brood was $31 \pm 27 \%$ (Table I; S1), with cells typically containing multiple foundresses. A total of 330 infested cells (single and multiple infested cells) were invaded by 569 foundress mites. This varied considerably by site; only $5 \pm 9 \%$ of drone cells were re-capped in nine colonies in the Stellenbosch area (Table S1-R* colonies), whereas three colonies from the Pniel (Table S1-PA* colonies) region in the next valley re-capped $65 \%$ of all drone cells. However, the proportion of infested $(66 \%)$ and noninfested $(65 \%)$ cells re-capped were similar. Therefore, a pattern of targeting mite-infested drone cells was not seen (Table I; Figure S1). The single drone frame from A. m. scutellata showed the same pattern, of high infestation $(57 \%)$, low re-capping $(2 \%)$ and multiple foundresses in cells (Tables I and S1). 

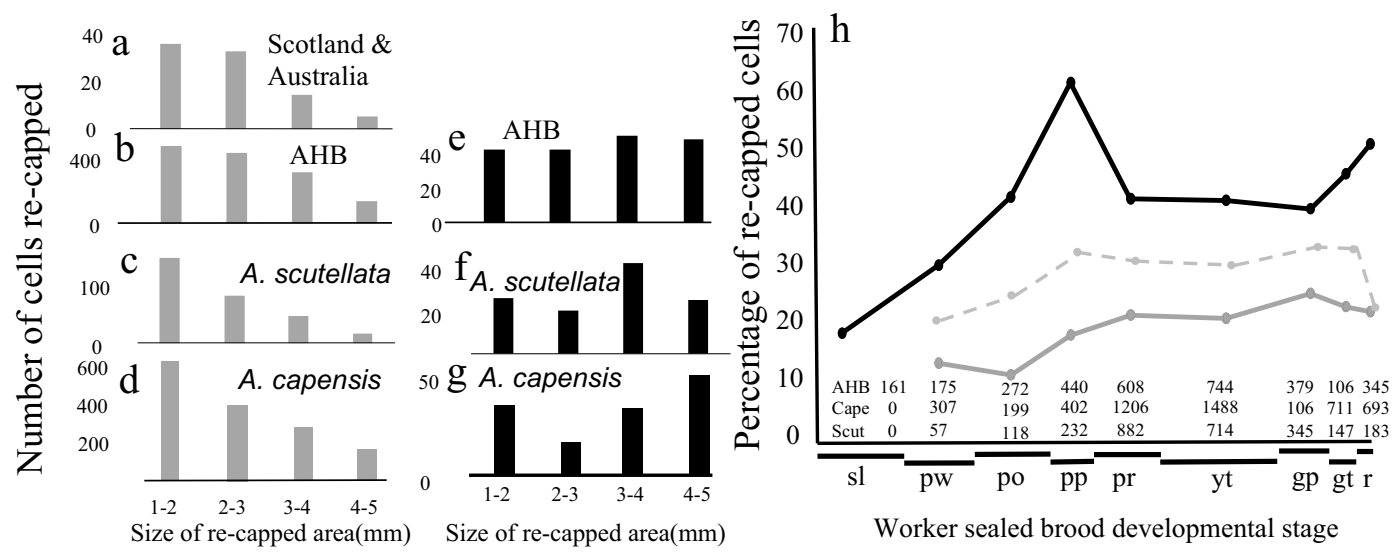

Figure 1. a-g Frequency distributions in the diameter of the re-capped area in non-infested cells (grey, $\mathbf{a}-\mathbf{d}$ ) and Varroa-infested cells (black, $\mathbf{e}-\mathbf{g}$ ) in the four study groups. $\mathbf{h}$ Percentage of re-capped cells at each stage of pupal development in AHB (black line), A. m. scutellata (solid grey line), and A. m. capensis (dashed grey line). The pupal developmental stages following (Martin 19) are sl = stretched larvae, $\mathrm{pw}=$ white-eyed, $\mathrm{po}=$ pale-eyed, $\mathrm{pp}=$ pinkeyed, $\mathrm{pr}=$ purple-eyed, $\mathrm{yt}=$ yellow thorax, $\mathrm{gp}=$ grey $\mathrm{pad}$, and $\mathrm{gt} / \mathrm{r}=$ grey thorax $/$ resting and total number of cells opened per stage is also given.

\subsection{Detection and removal of artificially mite infested cells in A. m. capensis}

Of the 392 A. m. capensis worker pupae artificially infested with mites (326 alive and 66 dead), only $3 \%$ were removed within $24 \mathrm{~h}$, most likely due to the experimental opening and resealing of the cell (manipulation). After 10 days, we found $21(5 \%)$ cells containing no mites or evidence of mites, i.e., mite fecal droppings on the cell wall, which must have escaped during the uncapping/re-capping process, and a further $30(8 \%)$ mites had become sealed into the cell wall and died during the spinning of the pupal cocoon. The mites lost due to manipulation, the re-capping process or being sealed into the cell wall were removed prior to the analysis of removal behavior. Across the 11 colonies, $32 \%$ of the infested cells had been removed after six days, and this increased to $54 \%$ after 10 days (Table S3). The percentage of dead $(47 \%)$ and alive $(46 \%)$ mites removed after 10 days were not significantly different $(U=49.5$, $p=0.75$ ). Of the remaining 152 artificially infested cells, $83 \%$ had been re-capped, while only $27 \%$ of mite free cells 'control' cells were recapped (Table S3). Again, typically larger recapped areas were found in infested cells relative to neighboring non-infested control cells (Figure 2); however, there were no significant differences in sizes of the re-capped area both between non-infested controls and cells containing dead mites trapped in the walls, and between infested cells that contained living or dead mites (Figure 2).

\subsection{Test for hygienic behavior using freeze- killed brood}

Among ten AHB colonies tested for both classic hygienic and re-capping behavior, a Spearman's rank correlation found no significant correlation $\left(r_{s}=0.03, p=0.93\right)$ between the two behaviors after $24 \mathrm{~h}$ (Table S3), with 19-98\% of the dead brood having been removed in $24 \mathrm{~h}$ while the re-capping rates ranged from 4-50\%. A similar result $\left(r_{s}=0.356, p=0.282\right)$ was also found across the $11 \mathrm{~A}$. m. capensis colonies (Table S3), with $48-100 \%$ of freeze-killed brood removed while the range of re-capping rates was $12-66 \%$. However, there was a weakly significant positive correlation $\left(r_{s}=0.67, p=0.024\right)$ between the removal rate of freeze-killed brood and the proportion of artificially infested cells removed (Table S3). 


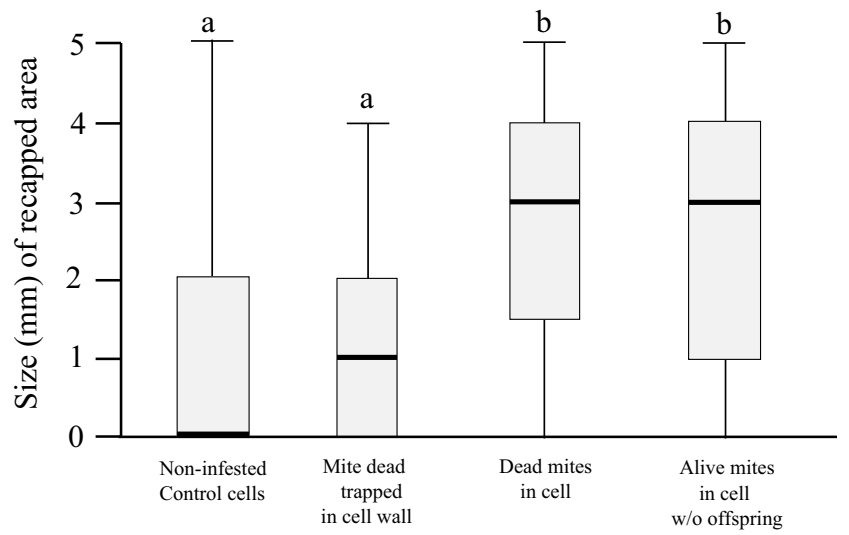

Figure 2. Box plots showing the size of the re-capped area of A. m. capensis at 11 days post-capping among four groups of cells (11 colonies). Kolmogorov-Simirnov analysis showed different frequency distributions of re-capped areas between the four groups of brood cells $\left(D_{(499,3)}=69.4, p<0.0001\right)$. Pairwise comparisons between the four groups showed that there was no significant difference between the mites trapped in cell walls and non-infested control cells $(D=0.678, p=0.41)$, nor between the cells in which dead and live mites were found $(D=0.839, p=$ 0.36 ). However, there were significant differences between the cells containing mites (dead or alive) and those cells that were either mite-free or contained mites trapped in the cell wall $(D>11, p$ always $<0.005)$.

\section{DISCUSSION}

Although we observed the re-capping of brood cells in all colonies, the re-capping rates were lowest in Varroa-naïve, and the highest were consistently found in worker brood of mite-resistant populations from Brazil (AHB) and South Africa (A. m. scutellata and A. m. capensis), as well as Europe (Oddie et al. 38). The key behavior in all these mite-resistant populations appears to be the bees' ability to detect mite-infested cells, as indicated by consistently higher re-capping rates of infested cells relative to non-infested cells, particularly since infestation rates are typically below $10 \%$ (Figure 3; Figure S1). The initial detection of a possible infested cell leads to the opening of a small hole in the cell cap that could allow better access to any volatile or non-volatile cues, i.e., on the pupae, within the sealed cell (see below). If a non-infested cell is opened in error, the hole is re-capped and the disturbed area remains small $(1-2 \mathrm{~mm})$, but if infested, the hole is enlarged to 3-4 $\mathrm{mm}$ to gain better access (Figure 1). A second trigger, or lack thereof, causes the infested cell to either be re-capped or the pupa to be cannibalized (Figure 4). This idea is in line with previous studies (Gramacho 14; Arathi et al. 3) that found the initial step of detecting diseased brood does not necessarily lead to brood removal, with repeated uncapping and recapping prior to brood removal. The removal of pupae artificially infested with mites was $54 \%$ in A. m. capensis (this study), $33 \%$ in A. m. scutellata (Cheruiyot et al. 9), 10-25\% in AHB (Aumeier et al. 4), and up to $40 \%$ in a single mite-resistant population in the Netherlands (Panziera et al. 40). All values are well below the $99 \%$ removal of artificially infested worker cells in the mite's original host, A. cerana (Rath and Drescher 44).

Two recent studies have assumed that genetically derived host factors within the brood prevent the initiation of mite oogenesis, which accounts for the increase in non-reproduction of mites in resistant colonies. For example, Broeckx et al. (6) suggested brood pheromones fall to a level that prevents the mites reproducing, whereas Conlon et al. (10) suggested an ecdysone gene was linked to mite-resistance, since low ecdysone levels may prevent mite oogenesis, hence increasing non-reproduction in mites. However, the greater proportion of 


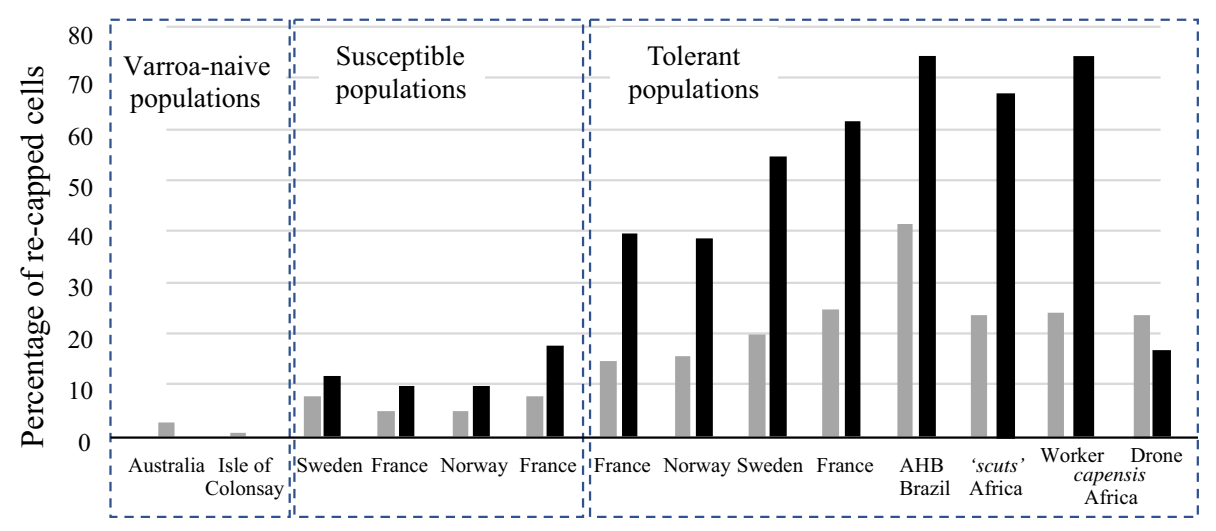

Figure 3. Re-capping levels of non-infested (grey) and Varroa-infested (black) worker cells, showing that in susceptible populations levels are consistently lower than those recorded in mite-resistant populations, except for the "capensis drone brood." The European data is taken from Oddie et al. (38), while the Australia, Colonsay, AHB, and Africa data are from the current study. "scuts" = A. m. scutellata $;$ capensis = A. m. capensis . For individual colony data, see Figure S1.

non-reproducing mites found in mite-resistant colonies (Martin et al. 25; Broeckx et al. 6) can simply be explained by the behavioral trait of increased disruption of mite reproduction. That is the removal of infested pupae reduces the number of successful mite reproductive cycles, increasing the proportion of non-reproductive mites in subsequent reproductive attempts. The latter may in part account for the lower reproductive values $(\mathrm{Wr})$ found in mite-resistant colonies, since a consistent $50 \%$ removal rate will result in $12.5-25 \%$ of mites never reproducing due to having been disturbed by the removal of pupae before mating. Since the number of mite reproductive cycles is estimated between 2 and 3 (Martin and Kemp 22), these mites may still invade cells and attempt to reproduce but produce either no offspring or only males (Martin et al. 25), both categories common in African (Martin and Kryger 23), AHB (Medina et al. 27 ) and this study. This would also explain why reproducing and non-reproducing mites could not be distinguished using DNA microsatellites (Broeckx et al. 6), since they do not represent two distinct genotypes, just that nonreproducing mites have either run out of sperm or eggs.

Mite reproductivity in re-capped and undisturbed infested cells was similar in this study (Table S2), which was also found in previous studies (Harris et al. 17; Oddie et al. 38). Mondet et al. (30) and Oddie et al. (38) have suggested that the bees are more likely to ignore cells containing non-reproducing mites (selection bias), while preferentially removing cells containing reproducing mites or with more offspring. However, we found no evidence for this in A. m. capensis since the removal rate of cells containing live (reproducing) and dead (non-reproducing) mites were similar, and Panziera et al. (40) also found no relationship between mite reproductive success and brood removal.

In both AHB (Mondragon et al. 32) and African honey bees (A. m. capensis and A. m. scutellata) (Tables I and S1), drone brood frequently becomes heavily infested, which may impact on the honey bee colony and population reproductive success. This can lead to density dependent control of the mite population via the drone brood (Martin and Medina 24), which occurs in A. cerana, either via a reduction in mite offspring survivorship in multiple infested brood (Martin 20) or increased failure for the bee to emerge (Rath 43). Recent studies have found that mite feeding causes A. cerana worker brood to die (Page et al. 39) via injection of a toxic mite salivary protein into the pupae during feeding (Zhang and Han 59), which could explain the high removal rates previously seen (Rath 43). 


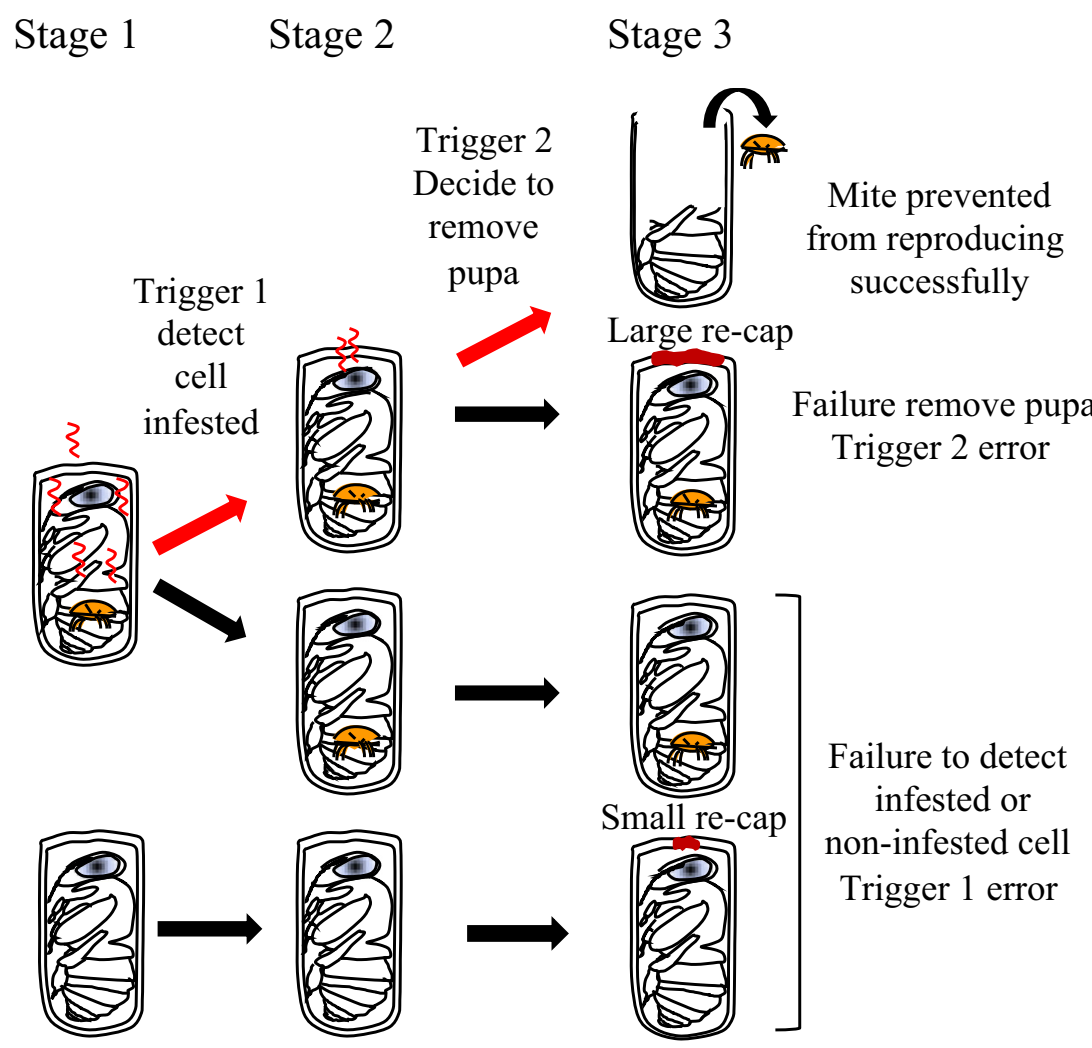

Figure 4. Process of detection of infested cells and subsequent removal of the pupa, and where errors are generated. Stage 1, a mite infested cell produces a stimulus detectable through the cell cap (Trigger 1). Stage 2, a small hole is made in the cap to allow a more detailed inspection. At this point a second trigger may be detected. Stage 3, if a mite is present and is detected the pupa is cannibalized and Varroa prevented from reproducing, if the mite is missed (or no mite is present) the cell is re-capped. The red arrows indicate the ideal situation and black arrows indicate observed errors due to the failure of one or both of the theorized behavioral triggers. The red wavy lines indicate the putative density of the mites' odor.

However, this salivary protein has no effect on A. mellifera pupa (Zhang and Han 59).

As only around $27 \%$ (Figure 3 ) of non-infested worker cells are re-capped, this suggests that initial detection of the mite is made without disturbing the cap. While the ability to detect mite infested cells is high in almost all mite resistant colonies (Figure S1 and Oddie et al. 38), it is the trigger to remove the infested pupa that remains error prone since only around 50\% of infested cells that are opened are subsequently removed in A. mellifera, and a high proportion of those cells are re-capped. The triggers for the initial detection and subsequent decision to cannibalize the pupa are both currently unknown (Figure 4), although this study indicates that olfaction could be a key factor for the initial detection as several previous studies have proposed (e.g., Rosenkranz et al. 47; Mondet et al. 29; Scannapieco et al. 49), since dead mites elicited a similar re-capping behavior as live mites, as also reported in A. cerana (Rath and Drescher 44). This suggests that motion or associated changes in the pupa (odour or temperature) may not be important as previously suggested by Aumeier and Rosenkranz (3) and Wagoner et al. (54). Nor would the level of oleic acid, which is known to trigger hygienic behavior (McAfee et al. 26), be important, unless also produced by the living mites. Furthermore, as mites sealed into the cell wall by the pupal cocoon 
did not elicit any increased re-capping response relative to non-infested cells (Figure 2), a volatile odour is a likely candidate. For example, Nazzi et al. (35) found pentadecane $\left(\mathrm{C}_{15} \mathrm{H}_{30}\right)$ was present only in the air of infested cells and the application of Z-(6)-pentadecene increased hygienic behavior, whereas Z-(7)-pentadecene, Z-(8)heptadecene and pentadecane had no effect. Longer cuticular hydrocarbons are unlikely to be the odour cue due to their lack of volatility, and the pupa's profile is mimicked precisely by the mite (Kather et al. 18). Rath and Drescher (44) also found that dead mites washed in ethanol were still removed at a high rate in A. cerana. However, Wagoner et al. (55) suggested that two long cuticular hydrocarbons (heptacosene $\left[\mathrm{C}_{27} \mathrm{H}_{54}\right]$ and tritriacontane $\left[\mathrm{C}_{33} \mathrm{H}_{66}\right]$ ) removed from the surface of the pupa were associated with the uncapping of infested worker brood. In addition, Mondet et al. (30) suggested changes in the brood pheromone that consists of ten ethyl and methyl esters can be detected between infested and non-infested brood, although this was found using discriminate analysis that is error prone if the sample to variable ratio is not high (Martin and Drijfhout 21; Mitteroecker and Bookstein 28 [Figure 5]).

Why re-capping behavior exists even in the Varroa-naïve populations is unknown, but when non-infested brood are not removed, any cost to colony fitness is minimal. We observed in African honey bee brood invaded by the lesser wax moth (Achroia grisella), cells were frequently re-capped rather than the pupae being removed. Likewise, $57 \%$ of the uncapped cells in a colony heavily infested with the greater wax moth (Galleria mellonella) were recapped within $24 \mathrm{~h}$ of uncapping (Villegas and Villa 53). Interestingly, the three $A . m$. capensis colonies at Pniel were unique in recapping high numbers of drone cells. These were all survivor colonies from an American Foulbrood (Paenibacillus larvae) outbreak. Therefore, making a small hole in the cell cap may be a general response to allow more detailed investigation of the developing pupa (which may account for the low-level presence of this trait in Varroa-naïve populations). After the arrival of the mites, this behavior appears to have been co-opted and selected for as part of a defense mechanism against Varroa; hence, the re-capping rate is elevated in all infested colonies (Figures 3 and S1), reaching the highest levels in mite-resistant colonies. Throughout Brazil and Africa, beekeeping pest management is minimal and so selective pressures for such traits have always been high. The constant management of a wide range of brood pest and pathogens throughout the Northern Hemisphere removes much of this selective pressure. In this and in previous studies (Oddie et al. 38), the ability to detect mites (Figure S1) and remove infested brood (Table S3) is highly variable. No doubt colony composition plays a role since recapping occurred most in mixed colonies rather than in highly hygienic or highly nonhygienic colonies (Arathi et al. 2).

Mondragon et al. (31) suggested hygienic behavior towards freeze-killed brood may not correlate closely with hygienic behavior towards Varroa mites. We found no correlation between re-capping levels and removal of freeze-killed brood. We did, however, find a weak positive correlation between the ability of a colony to remove freeze-killed brood and the removal of artificial mite-infested cells, which is similar to data from Spivak (50), where colonies selected for their ability to remove freeze-killed brood removed significantly more artificially miteinfested cells than "non-hygienic" colonies in 1 year but not another. Perez and Johnson (41) indicate that task specialization, e.g., hygienic behavior can be used to predict specialization in other related tasks, which may help explain the weak link, between response to freeze-killed brood and removal of living mite infested brood.

It appears that resistance towards Varroa mites in both A. cerana and A. mellifera is following a similar path, that of targeting mites invading worker cells and not drone cells, which will eventually lead to the combined effect of lower mite reproductive success in worker brood and densitydependent control in drone brood. As the ability of the bees to detect mites within worker cells, evidenced by increased re-capping, has arisen naturally in A. mellifera in five different countries, this may prove to be an excellent proxy for mite resistance. The challenge will be selecting for these traits (the abilities to initially detect and 
subsequently remove infested pupae) while moving away from a regime using insecticides, especially in large commercial beekeeping operations.

\section{ACKNOWLEDGMENTS}

We would like to thank Michael Duncan the technical officer of Western Sydney University for help with providing the honey bee frames. Catherine Taylor and Lauran Agnew of Salford University for assistance with the Varroa-naïve frames. In Brazil, thanks go to Jossimara Neiva de Jesus and Carlos Alfredo Lopes de Carvalho of UFRB for help with and access to the bees, and Christiaan Fransman for field assistance in South Africa. Finally, the British Beekeeping Association for supporting Natasha Reece who worked on the African bees and Hort Frontiers Pollination Fund for supporting L. E. Brettell.

\section{AUTHOR CONTRIBUTIONS}

S.J.M. conceived and designed the study; L. E. B. performed the study in Australia; G. P. H., N. R. and M. H. A. assisted with the study in South Africa and M. E. C. assisted with the field work in Brazil. S. J. M. analyzed the data drafted the manuscript with input from G. P. H., N. R. and M. E. C. The manuscript was edited by S. J. K., G. P. H., L. E. B and M. H. A.

\section{COMPLIANCE WITH ETHICAL STANDARDS}

Conflict of interest The authors declare that they have no conflict of interest.

\section{OPEN ACCESS}

This article is distributed under the terms of the Creative Commons Attribution 4.0 International License (http://creativecommons.org/licenses/by/4.0/), which permits unrestricted use, distribution, and reproduction in any medium, provided you give appropriate credit to the original author(s) and the source, provide a link to the Creative Commons license, and indicate if changes were made.

Reproduction de Varroa destructor et réoperculation dans les populations d'Apis mellifera résistantes aux acariens. réoperculation / hygiène / tolérance / résistance / Varroa.

Varroa destructor Reproduktion und Brutzellen-"Recapping" bei varroaresistenten Apis mellifera Populationen.

\section{Recapping / Hygiene/ Toleranz / Resistenz / Varroa}

\section{REFERENCES}

Allsopp, M. H. (2006) Analysis of Varroa destructor infestation of southern African honey bee populations. MSc dissertation. University of Pretoria, Pretoria, South Africa.

Arathi, H. S., Ho, G., Spivak, M. (2006) Inefficient task partitioning among nonhygienic honeybees, Apis mellifera L., and implications for disease transmission. Anim. Behav. 72, 431-438

Aumeier, P., Rosenkranz, P. (2001) Scent or movement of Varroa destructor mites does not elicit hygienic behavior by Africanized and Carniolan honey bees. Apidologie 32, 253-263

Aumeier, P., Rosenkranz P., Goncalves, L. S. (2000) A comparison of the hygienic response of Africanized and European (Apis mellifera carnica) honey bees to Varroa-infested brood in tropical Brazil. Genet. Mol. Biol. 23, 4. https://doi.org/10.1590/S141547572000000400013

Boecking, O. (1992) Removal behavior of Apis mellifera colonies towards sealed brood cells infested with Varroa jacobsoni: techniques, extent and efficacy. Apidologie 23, 371-373

Broeckx, B. J. G., De Smet, L., Blacquière, T., Maebe, K., Khalenkow, M., Van Poucke, M., et al. (2019) Honey bee predisposition of resistance to ubiquitous mite infestations. Sci. Rep. 9, 7794

Büchler, R., Berg, S., Le Conte, Y. (2010) Breeding for resistance to Varroa destructor in Europe. Apidologie, 41, 393-408

Camazine, S. (1986) Differential Reproduction of the Mite, Varroa jacobsoni (Mesostigmata: Varroidae), on Africanized and European Honey bees (Hymenoptera: Apidae). Annls. Entomol. Soc. Am. 79, 801-803

Cheruiyot, S. K., Lattorff, H. M. G., Kahuthia-Gathu, R., Mbugi, J. P., Muli, E. (2018) Varroa-specific hygienic behavior of Apis mellifera scutella in Kenya. Apidologie, 49, 439-449

Conlon, B. H., Aurori, A., Giurgiu, A.-I., Kefuss, J., Dezmirean, D. S., Moritz, R. F. A., Routtu, J. (2019) A gene for resistance to the Varroa mite (Acari) in honey bee (Apis mellifera ) pupae. Mol. Ecol. (online first) https://doi.org/10.1111/mec. 15080 
Dietemann, V., Nazzi, F., Martin, S. J., Anderson, D., Locke, B. et al. (2013) Standard methods for Varroa research. In V. Dietemann; J. D. Ellis; P. Neumann (Eds) The COLOSS BEEBOOK, Volume II, standard methods for Apis mellifera pest and pathogen research. J. Apic. Res. 51 , 1-54

Fries, I., Imdorf, A., Rosenkranz, P. (2006) Survival of mite infested (Varroa destructor) honey bee (Apis mellifera) colonies in a Nordic climate. Apidologie, 37, 564-570

Fuchs, S. (1989) The distribution of Varroa jacobsoni on honey bee brood combs and within brood cells as a consequence of fluctuating infestation rates. In: European Research on Varroatosis Control (Cavalloro R, ed), Balkema Rotterdam.

Gramacho, K. P. (1999) Fatores que interferem no comportamento higiênico das abelhas Apis mellifera. Ph.D. thesis, Faculdade de Filosofia, Ciênciase Letrasde Ribeirao Preto, Universidadede Sao Paulo, Brasil.

Harris, J. W. (2007) Bees with varroa sensitive hygiene preferentially remove mite infested pupae aged less than five days post capping. Bee World 46, 134-139

Harris, J. W. (2008) Effect of brood type on Varroa-sensitive hygiene by worker honey bees (Hymenoptera: Apidae). Annls. Entomol. Soc. Am. 101, 1137-1144

Harris, J. W., Danka, R. G., Villa, J. D. (2012) Changes in Infestation, Cell Cap Condition, and Reproductive Status of Varroa destructor (Mesostigmata: Varroidae) in Brood Exposed to Honey bees with Varroa Sensitive Hygiene. Annls. Entomol. Soc. Am. 105, 512-518.

Kather, R., Drijfhout, F. P., Shemilt, S., Martin S. J. (2015) Evidence for Passive Chemical Camouflage in the Parasitic Mite Varroa destructor. J. Chem. Ecol. 41, 178-186

Martin, S. J. (1994) Ontogenesis of the mite Varroa jacobsoni Oud. in worker brood of the honey bee Apis mellifera L. under natural conditions. Exp. Appl. Acarol. 18, 87-100

Martin, S. J. (1995) Reproduction of Varroa jacobsoni in cells of Apis mellifera containing one or more mother mites and the distribution of these cells, J. Apicul. Res. 34, 187-196

Martin, S. J., Drijfhout, F. P. (2009) How reliable is the analysis of complex cuticular hydrocarbon profiles by multi-variate statistical methods? J. Chem. Ecol. 35, 375-382.

Martin, S. J., Kemp, D. (1997) Average number of reproductive cycles performed by the parasitic mite Varroa jacobsoni in Apis mellifera colonies. J. Apicul. Res. 36, 113-123

Martin, S. J., Kryger, P. (2002) Reproduction of Varroa destructor in South African honey bees, does cell space influence Varroa male survivorship? Apidologie 33, 51-61

Martin, S. J., Medina, L. M. (2004) Africanized honey bees possess unique tolerance to Varroa mites. Trends Parasitol. 20, 112-114
Martin, S. J., Holland, K., Murray, M. (1997) Nonreproduction in the honeybee mite Varroa jacobsoni. Exp. Appl. Acarol. 21, 539-549

McAfee, A., Chapman, A., Iovinella, I., Gallagher-Kurtzke, Y., Collins, T. F., Higo, H., Madilao, L. L., Pelosi, P., Foster, L. J. (2018) A death pheromone, oleic acid, triggers hygienic behavior in honey bees (Apis mellifera L.). Sci. Rep. 8, 5719

Medina, M. L., Martin, S. J., Montaño, L., Ratnieks, F. L. W. (2002) Reproduction of Varroa destructor in worker brood of Africanized honey bee (Apis mellifera). Exp. Appl. Acarol. 27, 79-88

Mitteroecker, P., Bookstein F. (2011) Linear Discrimination, Ordination, and the Visualization of Selection Gradients in Modern Morphometrics. Evol. Biol. 38, 100-114

Mondet, F., Alaux, C., Severac, D., Rohmer, M., Mercer, A. R., Le Conte, Y. (2015) Antennae hold a key to Varroasensitive hygiene behaviour in honey bees. Sci. Rep. 5,10454

Mondet, F., Kim, S. H., de Miranda, J. R., Beslay, D., Le Conte, Y., Mercer, A. R. (2016) Specific Cues Associated With Honey Bee Social Defence against Varroa destructor Infested Brood. Sci. Rep. 6, 25444

Mondragon, L., Spivak, M., Vandame R. (2005) A multifactorial study of the resistance of honey bees Apis mellifera to the mite Varroa destructor over one year in Mexico. Apidologie 36, 345-358

Mondragon, M., Martin, S. J., Vandame, R. (2006) Mortality of mite offspring, a major component of Varroa destructor resistance in Africanized honey bees. Apidologie 37, 67-74

Mordecai, G. J., Brettell, L., Martin, S. J., Dixon, D., Jones, I. M., Schroeder, D. C. (2016). Superinfection exclusion and the long-term survival honey bees in Varroainfested colonies. ISEM J 10, 1182-1191

Moretto, G., Gonçalves, L. S., De Jong, D., Bichuette, M. Z. (1991) The effects of climate and bee race on Varroa jacobsoni Oud infestations in Brazil. Apidologie 22, 197-203

Nazzi, F., Della Vedova, G., D’Agaro, M. (2004). A semiochemical from brood cells infested by Varroa destructor triggers hygienic behaviour in Apis mellifera . Apidologie, 35, 65-70

Nganso, B. T., Fombong, A. T., Yusuf, A. A., Pirk, C. W. W. (2018). Low fertility, fecundity and numbers of mated female offspring explain the lower reproductive success of the parasitic mite Varroa destructor in African honey bees. Parasitology 145, 1633-1639

Oddie, M., Dahle, B., Neumann, P. (2017) Norwegian honey bees surviving Varroa destructor mite infestations by means of natural selection. PeerJ 5, e3956. https://doi.org/10.7717/peerj.3956

Oddie, M. A. Y., Büchler, R., Dahle, B., Kovacic, M., Le Conte, Locke, B., de Miranda, J., Mondet, F., Neumann, P. (2018). Rapid parallel evolution overcomes global honey bee parasite. Sci. Rep. 8, 7704 
Page, P., Lin, Z., Buawangpong, N., Zheng, H., Hu, F., Neumann, P., et al. (2016). Social apoptosis in honey bee superorganisms. Sci. Rep. 6, 27210

Panziera, D., van Langevelde, F., Blacquière, T. (2017) Varroa sensitive hygiene contributes to naturally selected varroa resistance in honey bees. J. Apic. Res. 56, 635-642

Perez, A. A., Johnson, B. R. (2019) Task repertoires of hygienic workers reveal a link between specialized necrophoric behaviors in honey bees. Behav. Ecol. Sociobiol. 73, 123

Pirk, C. W. W., Strauss, U., Yusuf, A. A., Démares, F., Human, H. (2015) Honey bee health in Africa-a review. Apidologie, 47, 276-300. https://doi. org/10.1007/s13592-015-0406-6

Rath, W. (1999) Co-adaptation of Apis cerana Fabr. and Varroa jacobsoni Oud. Apidologie, 30, 97-110. https://doi.org/10.1051/apido:19990202

Rath, W., Drescher W. (1990) Response of Apis cerana Fabr. towards brood infested with Varroa jacobsoni Oud. and infestation rate of colonies in Thailand, Apidologie 21, 311-321

Rinderer, T. E., Harris, J. W., Hunt, G. J., de Guzman, L. I. (2010) Breeding for resistance to Varroa destructor in North America. Apidologie, 41, 409-424

Rosenkranz, P. (1999) Honey bee (Apis mellifera L.) resistance to Varroa jacobsoni Oud. in South America. Apidologie 30,159-172

Rosenkranz, P., Tewarson, N. C., Singh, A., Engels, W. (1993) Differential hygienic behaviour towards Varroa jacobsoni in capped worker brood of Apis cerana depends on alien scent adhering to the mites. J. Apicul. Res. 32,89-93. https://doi.org/10.1080 /00218839.1993.11101292

Rosenkranz, P., Aumeier, P., Ziegelmann, B. (2010). Biology and control of Varroa destructor. J. Invert. Pathol. 103, S96-S119

Scannapieco, A. C., Mannino, M. C., Soto, G., Palacio, M. A., Cladera, J. L., Lanzavecchia, S. B. et al. (2017) Expression analysis of genes putatively associated with hygienic behavior in selected stocks of Apis mellifera L. from Argentina. Insectes Soc. 64, 485-494
Spivak, M. (1996) Honey bee hygienic behavior and defense against Varroa jacobsoni, Apidologie 27, 245260

Spivak, M., Gilliam, M. (1993) Facultative expression of hygienic behaviour of honey bees in relation to disease resistance. J. Apic. Res. 32, 147-157

Thompson, J. N. (1998) Rapid evolution as an ecological process. Trends Ecol. Evol. 13, 329-332

Villegas, A. J., Villa, J. D. (2006) Uncapping of pupal cells by European bees in the United States as responses to Varroa destructor and Galleria mellonella. J. Apic. Res. 45, 203-206

Wagoner, K. M., Spivak, M., Rueppell, O. (2018) Brood Affects Hygienic Behavior in the Honey Bee (Hymenoptera: Apidae). J. Eco. Entomol. 111, 2520-2530

Wagoner, K., Spivak, M., Hefetz, A., Reams, T., Rueppell, O. (2019) Stock-specific chemical brood signals are induced by Varroa and Deformed Wing Virus, and elicit hygienic response in the honey bee. Sci. Rep. 9, 8753

Wenner, A.M., Thorp, R. W., Barthell, J. F. (2009) Biological control and Eradication of Feral Honey bee colonies on Santa Cruz Island, California: A Summary. Pages 327-335 in Damiani, C.C. and D.K. Garcelon (eds.) pp. 327-335. Proceedings of the 7th California Islands Symposium. Institute for Wildlife Studies, Arcata, C. A.

Whitfield, C. W., Behura, S. K., Berlocher, S. H., Clark, A. G., Johnston, J. S. et al. (2006) Thrice Out of Africa: Ancient and Recent Expansions of the Honey Bee, Apis mellifera. Science, 314, 642-645

Winston, M. L. (1992) The biology and management of Africanized honey bees. Annu. Rev. Entomol. 37, 173-93

Zhang, Y., Han, R. (2018) A Saliva Protein of Varroa Mites Contributes to the Toxicity toward Apis cerana and the DWV Elevation in A. mellifera. Sci. Rep. 8, 3387

Publisher's note Springer Nature remains neutral with regard to jurisdictional claims in published maps and institutional affiliations. 